\title{
AGRONOMIC PERFORMANCE OF COTTON AND SOYBEAN CULTIVATED UNDER DIFFERENT COVER CROPS AND LIME AND GYPSUM DOSES
}

\author{
DESEMPENHO AGRONÔMICO DO ALGODÃO E DA SOJA CULTIVADOS SOB \\ DIFERENTES PLANTAS DE COBERTURA E DOSES DE CALCÁRIO E GESSO
}

\author{
Leila BENART'1 ${ }^{\text {; }}$ Cassiano Garcia ROQUE²; Cid Naudi Silva CAMPOS²; \\ Renato de Melo PRADO ${ }^{3}$ Rafael Gonçalves VILELA ${ }^{1}$; Paulo Eduardo TEODORO ${ }^{2}$ \\ 1. Universidade Estadual Paulista "Julio de Mesquita Filho", Botucatu, SP, Brasil; 2. Universidade Federal de Mato Grosso do Sul, \\ Chapadão do Sul, MS, Brasil. eduteodoro@ hotmail.com; 3. Universidade Estadual Paulista "Julio de Mesquita Filho", Jaboticabal, SP, \\ Brasil.
}

\begin{abstract}
Soil management with the use of lime and agricultural gypsum can influence the development and yield of cotton and soybean crops. The use of cover crops avoids soil degradation and ensures nutrient cycling on the soil surface. In most cultivated species, the application of lime and agricultural gypsum provides corrections in the sub-surface soil, keeping the nutrients available. This study aimed to (i) verify whether cotton and soybean cultivated in succession to cover crops affect its agronomic performance and (ii) evaluate the influence of lime and gypsum doses on the agronomic performance of these crops. Two experiments were performed. The first experiment consisted of cotton cultivated in the off-season, and the second, of soybean cultivated in the regular season. The experiment was carried out under three plant residues (Urochloa ruziziensis, Pennisetum glaucum, and fallow area), combined with lime and gypsum doses. The experiment consisted of a completely randomized block design with four replications. For the cotton crop, only the gypsum doses influenced the variables plant height, initial and final population, and yield. Cover crops did not influence the agronomic performance of cotton and soybeans. The increase of lime doses resulted in a linear increase in cotton and soybean yield. The highest gympsum dose improved the agronomic performance of cotton plants; however, it only influenced the height of soybean plants.
\end{abstract}

KEYWORDS: Plant residues. Glycine max. Gossipium hirsutum. Green manure.

\section{INTRODUCTION}

In the no-tillage system (NTS), surface and subsurface calcium deficiency may be linked to aluminum toxicity. In the Brazilian Cerrado, the aluminum toxicity results in soil acidity, which affects the yield of the cultivated species (PRADO et al., 2003). The soil calcium content in the Brazilian agricultural area is lower than $0.4 \mathrm{cmolc}$ $\mathrm{dm}^{-3}$, and the aluminum saturation is higher than $10 \%$ in the subsurface. Thus, about $90 \%$ of the agricultural area is under these conditions, which hinders the development of plants roots and damages the nutrients and water absorption by plants (SOUZA, LOBATO; REIN, 2001).

The effect of liming in reducing soil acidity is quite slow since it is limited to the application area. When applied to the surface, liming does not guarantee the subsurface correction and requires the leaching of the carbonates to guarantee its efficiency in the deeper layers for better yield (BLUM et al., 2013). Therefore, agricultural gypsum, which presents higher mobility in the soil and acts as a conditioner, provides calcium $\left(\mathrm{Ca}^{2+}\right)$ and sulfur $\left(\mathrm{SO}^{-2}\right)$ in solution and guarantees the leaching of nutrients to the deeper soil layers, and reduces the aluminum toxicity in the subsurface (CAIRES et al., 2006).

The use of cover crops in a crop rotation system may be advantageous for soil properties and improve nutrient absorption and translocation efficiency (SANTOS et al., 2004; ZOTARRELI et al., 2012). Cover crops can increase crop yield in soil management in a more sustainable and economical way. This fact is due to better nutrient cycling and soil chemical, physical, and biological conditions (CARVALHO et al., 2019). However, the decomposition rate of plant residues in the Brazilian Cerrado is high owing to climatic characteristics, such as high temperatures and high humidity, which cause faster degradation (CARVALHO et al., 2011).

The decomposition of the plant material can affect nutrients availability, such as $\mathrm{N}, \mathrm{P}, \mathrm{K}, \mathrm{Mg}$, and $\mathrm{S}$, and increase soil $\mathrm{pH}$, generating organic compounds such as fulvic and humic acids. These compounds are crucial in the alleviation of stresses, development of the root system, and synthesis of enzymes. However, in the case of NTS, these compounds may not be detected in the short-term subsurface acidity mitigation (PAVINATO; 
ROSOLEM, 2008; CAIRES et al., 2008a). In this context, liming is an ideal management strategy to reduce the exchangeable $\mathrm{Al}$ and $\mathrm{Mn}$ in the soil. Nevertheless, when applied without incorporation, soil correction can be limited while in the soil surface. Thus, the application of agricultural gypsum gives necessary contribution for the satisfactory crop development.

The Cerrado soils are low fertile and highly acid with high aluminum content. Therefore, this study aimed to evaluate the agronomic performance of the soybean crop in succession to cover crops with the superficial application of lime and gypsum doses.

\section{MATERIAL AND METHODS}

The experiments were carried out in the experimental area of the Centro de pesquisas da Fundação de Apoio a Pesquisa Agropecuária de Chapadão do Sul - FUNDAÇÃO CHAPADÃO, in the municipality of Chapadão do Sul, MS (18 $41^{\circ} 33$ "S, 52 $42^{\circ} 45^{\prime}$ " W and altitude of $810 \mathrm{~m}$ ).

The climate of the region is wet and dry (Aw), according to Koppen, with well-defined seasons, characterized by rainy summer and dry winter. The average annual temperature in the coldest month is higher than $18^{\circ} \mathrm{C}$, ranging between $13^{\circ} \mathrm{C}$ and $28^{\circ} \mathrm{C}$ between seasons, with average annual rainfall of $1.850 \mathrm{~mm}$, and average annual relative humidity of $64.8 \%$ (Castro et al., 2012). Rainfall and air temperature data were recorded during the experimental period. (Figure 1).

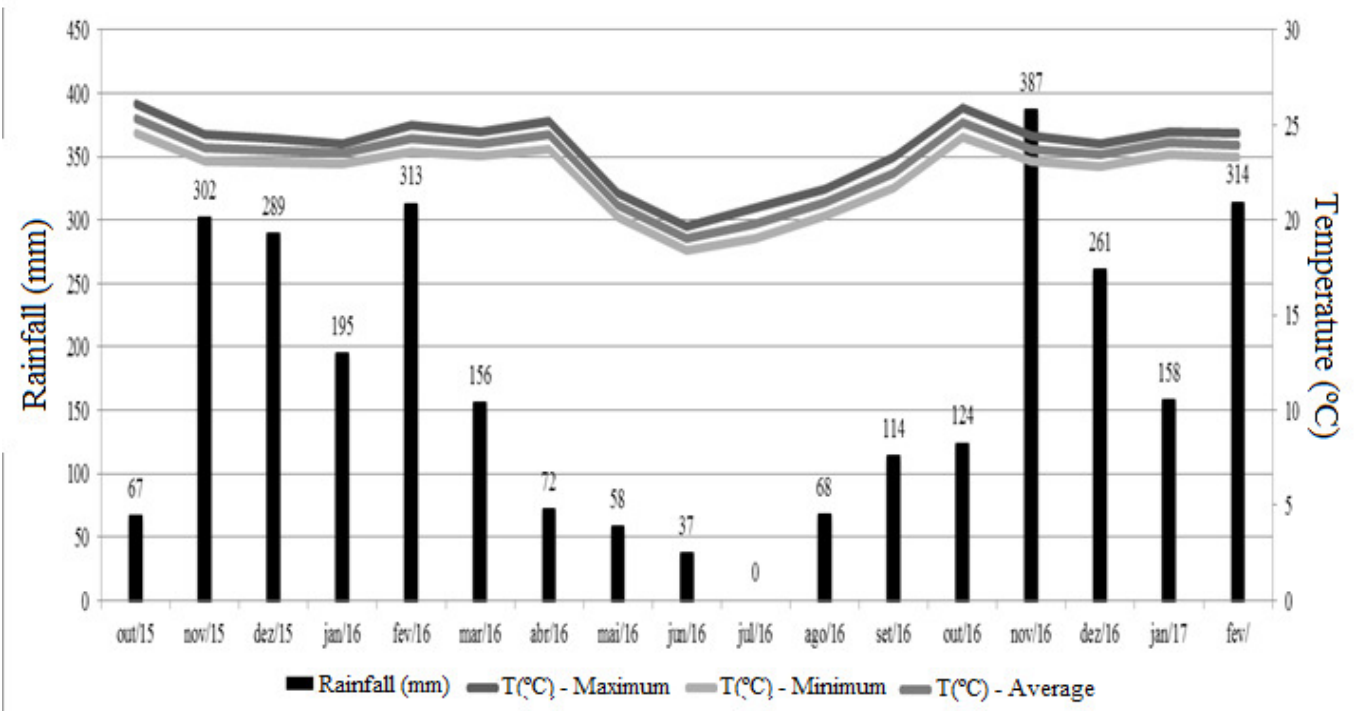

Figure 1. Rainfall and air temperatures during the experimental period. Source: INMET.

The soil of the experimental area was classified as Dystrophic Red Latosol, based on the methodology of Embrapa (2013). The classification is obtained by evaluating the morphological, physical, chemical, and mineralogical data of the profile that represents the soil. Environmental aspects are also taken into account, such as climate, vegetation, relief, soil external characteristics, water conditions, and source material. A soil sample was collected before the experiment installation, revealing the chemical analysis (Table 1) and the granulometric composition ( $46 \%$ clay, $51.5 \%$ sand, and $2.5 \%$ silt), evaluated in the 0.0-0.4 m layer.

Table 1. Soil chemical analysis before the experiment installation.

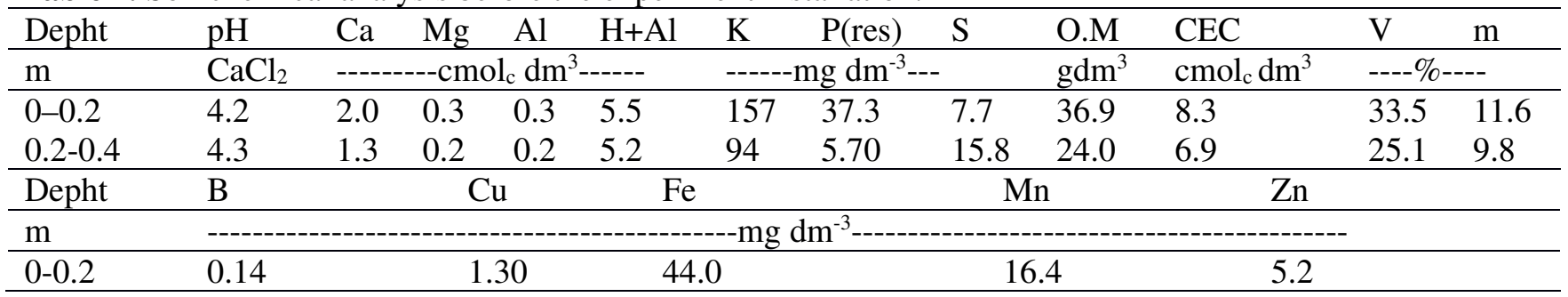


The experiment consisted of a completely randomized block design with four replications, in a split-plot scheme. The main plot consisted of two cover crops (Urochloa ruziziensis, Pennisetum glaucum) and one fallow treatment; the subplot consisted of agricultural gypsum $(0,2300$, and 4600 $\left.\mathrm{kg} \mathrm{ha}^{-1}\right)$; and the sub-sub-plot consisted of lime doses $\left(0,2000,4000\right.$, and $\left.6000 \mathrm{~kg} \mathrm{ha}^{-1}\right)$.

The experiment was carried out in the NTS area on September 15, 2015, with the application of lime, with $85 \%$ TNRP (total neutralization relative power). The application of agricultural gypsum (October 26, 2015) aimed at increasing the base saturation to $50 \%$, according to the recommendation of Souza and Lobato (2005). Lime and gypsum were applied to the surface without incorporation. Table 1 shows the soil chemical analysis of the experimental area before the experiment installation.

The increase the base saturation was the method used to calculate the need for liming (Raij et al., 1996). The method of Sousa and Lobato was used to determine the amount of agricultural gypsum to be applied. The soil clay content was determined by the gypsum dose of $2.3 \mathrm{Mg} \mathrm{ha}^{-1}$, the gypsum formulation used was $18 \% \mathrm{CaO}$ and $15 \%$ of S.

Cover crops were sown on October 8, 2015, with 5 and $15 \mathrm{~kg} \mathrm{ha}^{-1}$ of seeds of $U$. ruziziensis and $P$. glaucum (cv ADR 300), respectively, using mismatched discs, spaced at $0.17 \mathrm{~m}$ between rows. With the aid of a horizontal plant residue crusher (Triton), the cover crops were managed on January 15, 2016.On January 24, 2016, the material was dried using glyphosate $\left(1.98 \mathrm{~kg} \mathrm{ha}^{-1}\right.$ of a.i $)$ and carfentrazone-ethyl ( $20 \mathrm{~g} \mathrm{ha}^{-1}$ of a.i).

Afterwards, the cotton crop was implanted on February 4, 2016, obtaining a cycle of 190 days. The cultivar FM975WS (medium size, high fiber yield, great productive potential in the market) was used in the experiment. Base fertilization consisted of $120 \mathrm{~kg} \mathrm{ha}^{-1}$ of potassium, which was applied using a fertilizer seeder, with a front cutting disk and a fertilizer distribution system, spaced at $0.90 \mathrm{~m}$ between rows, and with seed density of nine seeds per meter.

The cotton crop had three plants per subsubplot evaluated for plant height (measured from the ground to the base of the last leaf insertion), weight of thirty bolls (measured with a precision digital scale) and yield in $\mathrm{kg} \mathrm{ha}^{-1}$. The crop was harvested on August 10, 2016.

The soybean crop was installed on October 18, 2016, with cultivar NA 5909 (undetermined growth habit, medium size, maturity group 5.9, intermediate fertility requirement). Base fertilization consisted of $150 \mathrm{~kg} \mathrm{ha}^{-1}$ MAP (11\% N - 52\% P2O5 $-00 \% \mathrm{~K} 2 \mathrm{O}$ ), which was applied using a fertilizersowing, with a front cutting disk and a fertilizer distribution system, spaced at $0.45 \mathrm{~m}$ between rows, and with seed density of 22 seeds per meter.

The soybean crop had three plants per subsubplot evaluated for plant height (measured from the ground to the base of the last leaf insertion), insertion of the first pod (measured from the ground to the base of the first pod insertion), weight of one hundred grains (measured with a precision digital scale), and grain yield. Grain yield was obtained by threshing and weighing the grains from all pods harvested in the useful area of the sub-subplots, which was converted to $\mathrm{kg} \mathrm{ha}^{-1}$.

Data were subject to analysis of variance, followed by the means comparison of gypsum doses and cover crops by the Tukey's test $(\mathrm{P}<0.05)$. Polynomial regression analysis was used for lime doses in the Sisvar software (FERREIRA, 2011).

\section{RESULTS AND DISCUSSION}

\section{Cotton agronomic performance}

Table 2 shows the summary of the analysis of variance for the cotton variables. The cover crop did not influence the cotton agronomic performance. Some factors hinder the yield of the crop cultivated in succession to cover crops. In the Brazilian Cerrado, the dry spell is characteristic in the rainy season; cover crops are sown in the spring/summer, which can reduce in productive potential (BURLE et al., 2006; CARVALHO et al., 2008). Thus, the low rainfall in the month of treatment implantation (October) may have contributed to the present results.

The gypsum application influenced plant height, initial stand, final stand, and cotton yield (Table 3). Similar results for cotton yield were observed by Sadic et al. (2003), who reported an increase in this variable when compared with the treatment without agricultural gypsum application.

The application of agricultural gypsum increases sulfur and calcium availability, and thus reduces the levels of toxic $\mathrm{Al}$ in the soil, favoring nutrient absorption (Sousa et al., 2005). This significant growth occurs due to the excessive availability of calcium and other nutrients, which improve soil fertility. Moreover, the gypsum application increases the root growth and carries nutrients to deeper layers (CAIRES et al., 2004 and 2008), and thus influences the crop development. 
Table 2. Summary of analysis of variance for plant height (PH), initial plant stand (IS), final plant stand (FS), weight of thirty bolls (WTB), and cotton yield (CY) of cotton plants cultivated under different cover crops and lime and gypsum doses.

\begin{tabular}{|c|c|c|c|c|c|c|}
\hline \multirow{2}{*}{ SV } & DF & $\mathrm{PH}$ & IS & FS & WTB & CY \\
\hline & \multicolumn{6}{|c|}{ Mean Square } \\
\hline Block & 3 & 1018.24* & $392.01 *$ & $668.33^{*}$ & $469.07^{\mathrm{ns}}$ & $14411.05^{\mathrm{ns}}$ \\
\hline Cover (C) & 2 & $105.11^{\mathrm{ns}}$ & $26.30^{\text {ns }}$ & $59.14^{\mathrm{ns}}$ & $16.75^{\mathrm{ns}}$ & $5095.83^{\mathrm{ns}}$ \\
\hline Gypsum (G) & 2 & $1162.67 *$ & $290.73^{\text {ns }}$ & $654.04^{*}$ & $70.75^{\mathrm{ns}}$ & $11294.39^{*}$ \\
\hline Lime (L) & 3 & $273.17^{\mathrm{ns}}$ & $68.23^{\text {ns }}$ & $153.61^{\text {ns }}$ & $537.07 *$ & $33988.20 *$ \\
\hline $\mathrm{C} \times \mathrm{G}$ & 4 & $9.37^{\mathrm{ns}}$ & $2.34^{\mathrm{ns}}$ & $5.25^{\mathrm{ns}}$ & $267.25^{\mathrm{ns}}$ & $2267.34^{\mathrm{ns}}$ \\
\hline $\mathrm{C} \times \mathrm{L}$ & 6 & $9.49^{\mathrm{ns}}$ & $2.36^{\mathrm{ns}}$ & $5.33^{\mathrm{ns}}$ & $341.38^{\mathrm{ns}}$ & $587.57^{\mathrm{ns}}$ \\
\hline Gx L & 6 & $72.73^{\mathrm{ns}}$ & $18.18^{\mathrm{ns}}$ & $40.91^{\mathrm{ns}}$ & $1196.60^{*}$ & $1775.29^{\mathrm{ns}}$ \\
\hline $\mathrm{C} \times \mathrm{G} \times \mathrm{L}$ & 12 & $16.15^{\text {ns }}$ & $4.03^{\mathrm{ns}}$ & $9.08^{\mathrm{ns}}$ & $201.32^{\mathrm{ns}}$ & $893.58^{\mathrm{ns}}$ \\
\hline Error 1 & 6 & 76.11 & 19.03 & 42.81 & 217.26 & 9512.64 \\
\hline Error 2 & 12 & 28.98 & 7.25 & 16.31 & 207.37 & 924.34 \\
\hline Error 3 & 37 & 37.11 & 9.25 & 20.87 & 188.83 & 862.11 \\
\hline CV $1(\%)$ & & 11.02 & 10.68 & 10.90 & 13.72 & 59.04 \\
\hline CV $2(\%)$ & & 6.80 & 6.59 & 6.73 & 13.41 & 18.50 \\
\hline CV $3(\%)$ & & 7.69 & 7.46 & 7.61 & 12.79 & 17.77 \\
\hline Mean & & 79.19 & 40.84 & 60.01 & 107.42 & 165.20 \\
\hline
\end{tabular}

Table 3. Means comparisons for the variables plant height (PH), initial stand (IS), final stand (FS), and cotton yield under different gypsum doses.

\begin{tabular}{lllll}
\hline Gypsum & PH & IS & FS & CY \\
\hline 0 & $73.68 \mathrm{~b}$ & $38.09 \mathrm{~b}$ & $55.86 \mathrm{~b}$ & $2254.92 \mathrm{~b}$ \\
2300 & $83.15 \mathrm{a}$ & $42.83 \mathrm{a}$ & $62.99 \mathrm{a}$ & $2527.80 \mathrm{ab}$ \\
4600 & $80.74 \mathrm{a}$ & $41.62 \mathrm{a}$ & $61.18 \mathrm{a}$ & $2730.41 \mathrm{a}$ \\
\hline
\end{tabular}

Means followed by different lowercase letters in the same column differ from each other by the Tukey's test at $5 \%$ probability.

Lime doses affected cotton yield, obtained by a linear regression, where the increase of the lime doses increased significantly crop yield (Figure 2). Silva et al. (1987b, 1995, 1997), with the repetition of liming in long-term trials, also observed a close relationship between cotton production and soil subsurface acidity correction.

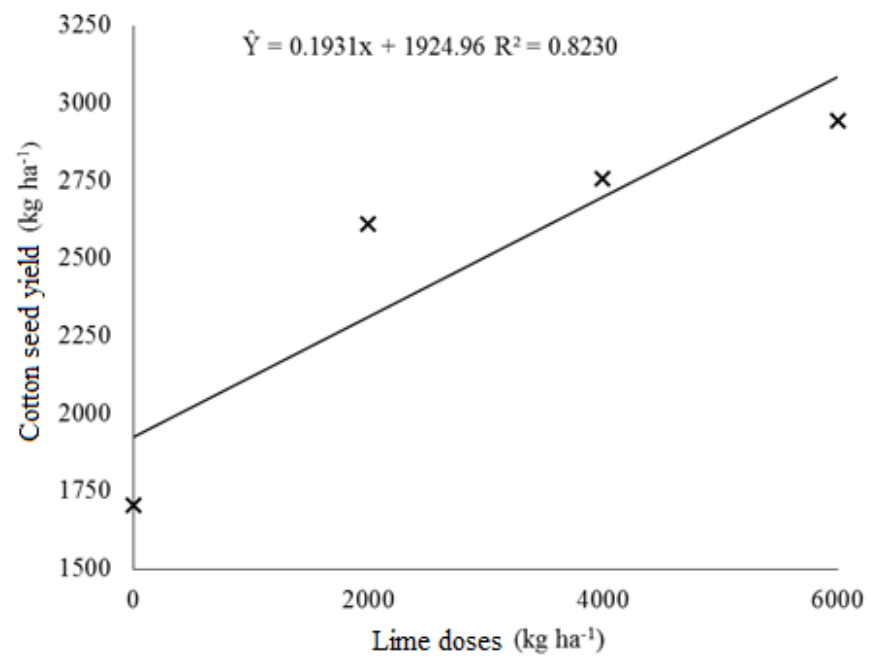

Figure 2. Cotton seed yield in relation to lime doses. 


\section{Soybean agronomic performance}

Table 4 shows the summary of the analysis of variance for the soybean variables. The cover crops did not influence the soybean agronomic performance. The climate of the Brazilian Cerrado provides faster decomposition (as in the case of Brachiaria ruziziensis, which has lower lignin content) and faster nutrient cycling, not providing a positive increase in the subsequent species. Conversely, Pennisetum glaucum presents higher lignin content, which guarantees better soil coverage (CARVALHO et al., 2008, 2009, 2011). Thus, the cover crops must be monitored in other seasons for the generalization of these results.

Table 4. Summary of the analysis of variance for plant height (PH), insertion of first pod (IFP), weight of one hundred grains (WHG), and grain yield (GY) of soybean cultivated under different cover crops and lime and gypsum doses.

\begin{tabular}{llllll}
\hline \multirow{2}{*}{ SV } & DF & PH & IFP & WHG & GY \\
\cline { 2 - 6 } & \multicolumn{5}{c}{ Mean square } \\
\hline Block & 3 & $270.05^{*}$ & $242.12^{*}$ & $1.39^{\text {ns }}$ & $677218.73^{\text {ns }}$ \\
Cover (C) & 2 & $114.72^{\text {ns }}$ & $22.67^{\text {ns }}$ & $0.58^{\text {ns }}$ & $1341409.45^{\text {ns }}$ \\
Gypsum (G) & 2 & $312.39^{*}$ & $0.13^{\text {ns }}$ & $0.41^{1 \text { ns }}$ & $36761.33^{\text {ns }}$ \\
Lime (L) & 3 & $77.59^{\text {ns }}$ & $6.01^{\text {ns }}$ & $6.52^{*}$ & $1139960.01^{*}$ \\
C x G & 4 & $100.43^{\text {ns }}$ & $0.99^{\text {ns }}$ & $0.09^{\text {ns }}$ & $67923.95^{\text {ns }}$ \\
C x L & 6 & $8.15^{\text {ns }}$ & $10.33^{\text {ns }}$ & $0.24^{\text {ns }}$ & $221379.88^{\text {ns }}$ \\
G x L & 6 & $50.59^{\text {ns }}$ & $5.12^{\text {ns }}$ & $0.35^{\text {ns }}$ & $59526.76^{\text {ns }}$ \\
C x G x L & 12 & $32.42^{\text {ns }}$ & $3.40^{\text {ns }}$ & $0.34^{\text {ns }}$ & $147206.32^{\text {ns }}$ \\
Error 1 & 6 & 28.04 & 6.00 & 0.42 & 251966.73 \\
Error 2 & 12 & 27.21 & 2.45 & 0.06 & 81861.34 \\
Error 3 & 37 & 27.24 & 7.45 & 0.24 & 140547.58 \\
\hline CV 1 (\%) & 7.39 & 16.27 & 3.57 & 9.77 \\
\hline CV 2 (\%) & 7.28 & 10.39 & 1.32 & 5.57 \\
\hline CV 3 $(\%)$ & & 7.29 & 18.12 & 2.71 & 7.30 \\
\hline Mean & & 71.61 & 15.06 & 18.26 & 5136.99 \\
\hline \hline
\end{tabular}

SV: source of variation; CV: coefficient of variation; DF: degrees of freedom; ns and *: not significance and significance at 5\% de probability by F-test, respectively.

The doses of agricultural gypsum influenced only plant height in soybean plants (Table 4). The application of the recommended agricultural gypsum dose provided the greatest plant height (Figure 3). Other researches verified that the application of gypsum did not increase soybean grain yield (CAIRES et al., 2003 and 2006; NOGUEIRA; MELO 2003; MASCHIETTO 2009), corroborating the results of the present study.

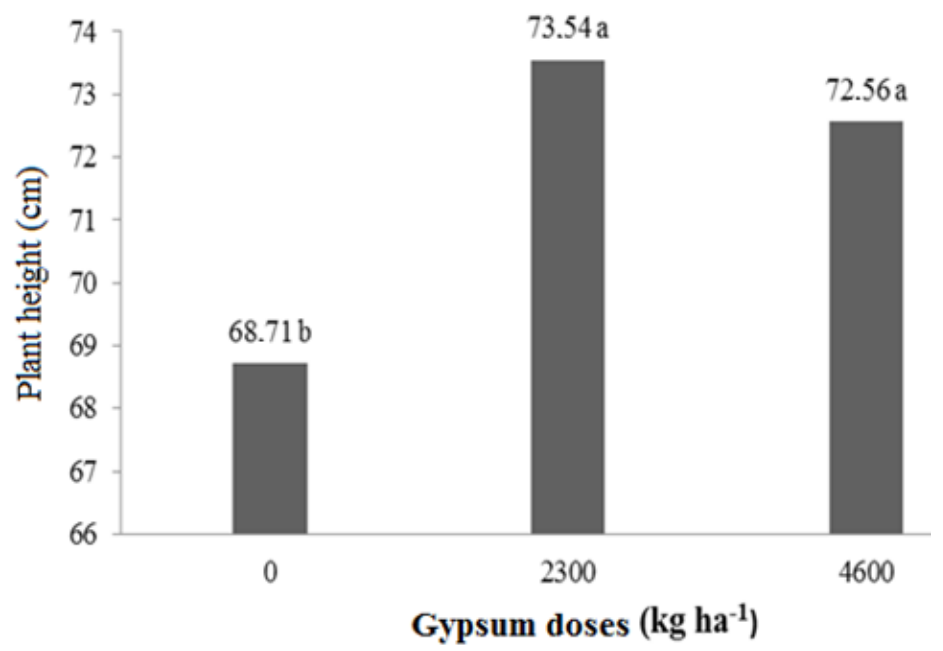

Figure 3. Plant height of soybean in function of agricultural gypsum doses. 
The lime doses influenced only the weight of one hundred grains and the grain yield of the soybean crop (Table 2). A linear increase was detected for these variables in function of the increase of lime doses (Figures 4 and 5, respectively). Quaggio et al., (1993), when incorporating lime in the first cultivation year, verified improvement in the conditions in the development of the crop, such as the root environment. The lime application improves the chemical soil condition by increasing the $\mathrm{pH}$ and reducing the potential acidity, which results in positive growth in the root development and plant absorption, and thus improves soil yield.

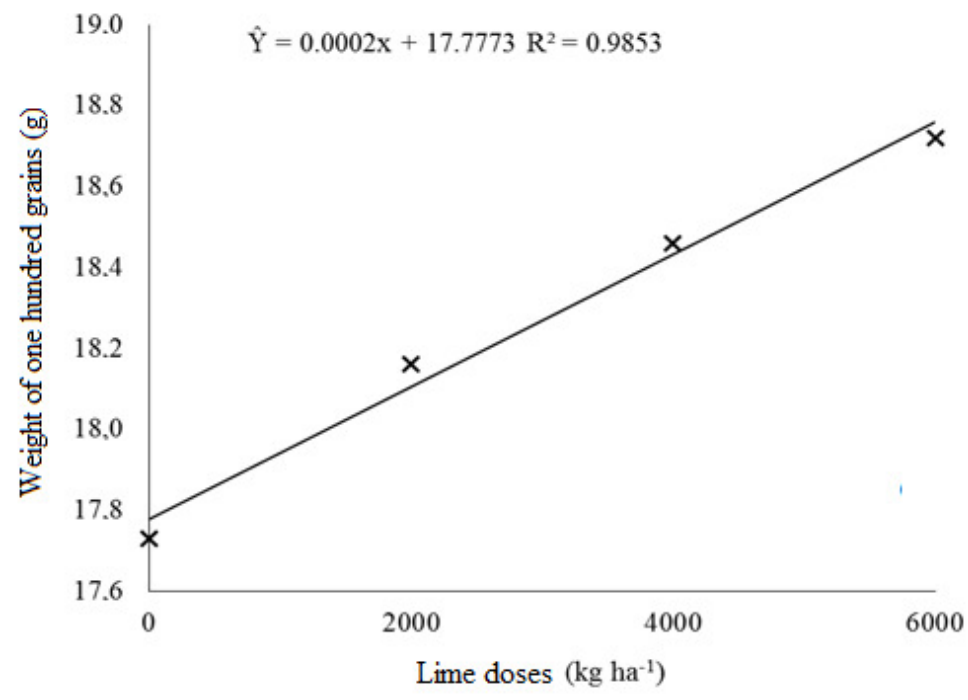

Figure 4. Weight of one hundred grains of the soybean in relation to the lime doses.

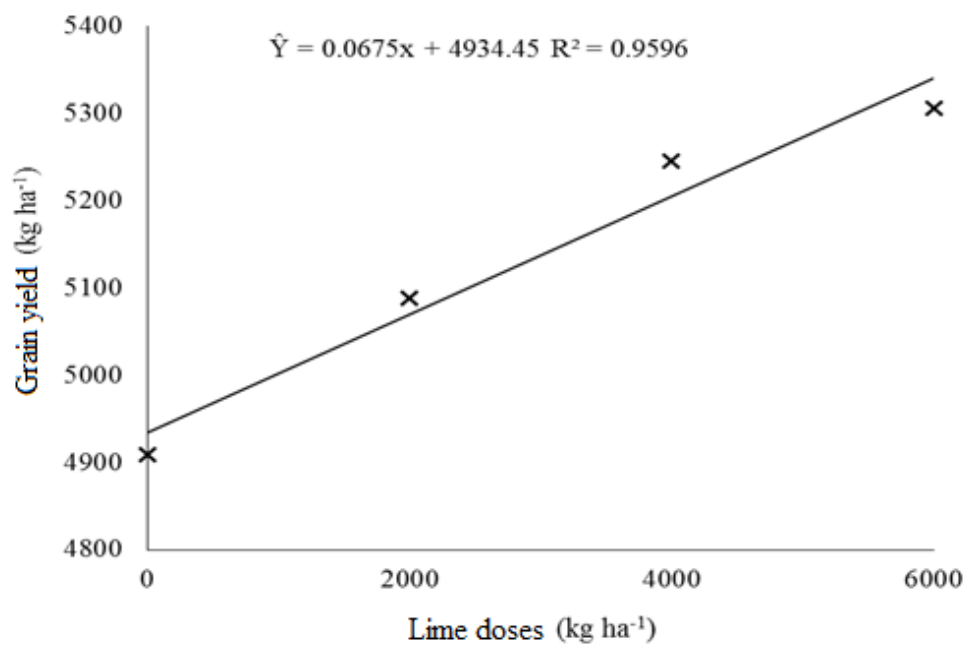

Figure 5. Grain yield of soybean in relation to lime doses.

Tomelero et al. (2016) stated that the application of lime increases soybean yield. The authors also affirmed that lime increases soybean nodulation due to soil $\mathrm{pH}$ correction, which is favorable for nodulation. No interactions were detected between the factors studied for both the agronomic performance of cotton and soybean crops (Tables 2 and 3). These results allow recommending the cultivation of cotton (off-season) and soybean under fallow and the application of the highest gypsum and lime doses to obtain the highest yield in these crops.

\section{CONCLUSIONS}

Cover crops do not influence the agronomic performance of cotton and soybean crops.

The increase of lime doses resulted in a linear increase in cotton and soybean yield.

The application of the highest agricultural gypsum dose improved the agronomic performance of cotton, but only influenced plant height in the soybean crop. 
RESUMO: O manejo do solo com o uso de calcário e gesso agrícola pode influenciar o desenvolvimento e produtividade das culturas de algodão e soja. O uso de culturas de cobertura evita a degradação do solo e garante a ciclagem de nutrientes na superfície do solo. Na maioria das espécies cultivadas, a aplicação de cal e gesso agrícola fornece correções no solo subsuperficial, mantendo os nutrientes disponíveis. Este estudo objetivou (i) verificar se o algodão e a soja cultivados em sucessão à cobertura vegetal afeta seu desempenho agronômico e (ii) avaliar a influência das doses de calcário e gesso no desempenho agronômico dessas culturas. Dois experimentos foram realizados. O primeiro experimento consistiu de algodão cultivado no período de entressafra e o segundo de soja cultivada na estação regular. O experimento foi conduzido sob três resíduos vegetais (Urochloa ruziziensis, Pennisetum glaucum e pousio), combinados com doses de cal e gipsita. O experimento consistiu de um delineamento de blocos ao acaso, com quatro repetições. Para a cultura do algodoeiro, apenas as doses de gesso influenciaram as variáveis altura da planta, população inicial e final e produtividade. As culturas de cobertura não influenciaram o desempenho agronômico do algodão e da soja. $\mathrm{O}$ aumento das doses de calcário resultou em um aumento linear no rendimento de algodão e soja. A maior dose de gesso melhorou o desempenho agronômico das plantas de algodão; no entanto, influenciou apenas a altura das plantas de soja.

PALAVRAS-CHAVE: Resíduos vegetais. Glycine max. Gossipium hirsutum. Adubo verde.

\section{REFERENCES}

CAIRES, E. F.; BLUM, J.; BARTH, G.; GARBUIO, F. J.; KUSMAN, M. T.. Alterações químicas do solo e resposta da soja ao calcário e gesso aplicados na implantação do sistema plantio direto. Revista Brasileira de Ciência do Solo, Viçosa, v. 27, n. 2, p. 275-286, 2003. https://doi.org/10.1590/S0100-06832003000200008

CAIRES, E. F.; KUSMAN, M. T.; BARTH, G.; GARBUIO, F. J.; PADILHA, J. M. Alterações químicas do solo e resposta do milho à calagem e aplicação de gesso. Revista Brasileira de Ciência do Solo, v. 28. p.125-136, 2004. https://doi.org/10.1590/S0100-06832004000100013

CAIRES, E. F.; CHURKA, S.; GARBUIO, F. J.; FERRARI, R. A.; MORGANO, M. A. Soybean yield and quality as a function of lime and gypsum applications. Scientia Agrícola, Piracicaba, v. 63, n. 4, p. 370-379, 2006. https://doi.org/10.1590/S0103-90162006000400008

CAIRES, E. F.; PEREIRA FILHO, P. R. S.; ZARDO FILHO, R.; FELDHAUS, I. C. Soil acidity and aluminium toxicity as affected by surface liming and cover oat residues under a no-till system. Soil Use and Management, v. 24, n. 3, p. 302-309, 2008. https://doi.org/10.1111/j.1475-2743.2008.00166.x

CARVALHO, A. M. de; BUSTAMANTE, M.M. da C.; SOUSA JUNIOR, J.G de A.; VIVALDI, L. J. Decomposição de resíduos vegetais em Latossolo sob cultivo de milho e plantas de cobertura. Revista Brasileira de Ciência do Solo, Viçosa, MG, v.32, p. 2831 - 2838, nov/dez. 2008. https://doi.org/10.1590/S0100-06832008000700029

CARVALHO, A.M de; BUSTAMANTE, M. M. C.; ALCANTARA, F. A.; RESCK, I. S.; LEMOS, S.S. Characterization by solid - state CPMAS 13C NMR spectroscopy of decomposing plant residues in conventional and no-tillage systems in Central Brazil. Soil and Tillage Research, Amsterdam, v. 102, n.1, p. 144-150, Jan. 2009. https://doi.org/10.1016/j.still.2008.08.006

CARVALHO, A. M. de; SOUZA; SOUZA, L. L. P. de; GUIMARÃES JUNIOR, R.; ALVES, P. C. A. C.; VIVALDI, J. L. cover crops with potential use for crop- livestock integrated systems in the cerrado region. Pesquisa Agropecuária Brasileira, Brasilia, DF, v. 46, n. 10, p. 1200-1205, out. 2011. https://doi.org/10.1590/S0100-204X2011001000012 
MASCHIETTO, E. H. G. Gesso agrícola na produção de milho e soja em solo de alta fertilidade e baixa acidez em subsuperfície em plantio direto. 2009. 56 f. Dissertação (Mestrado em Agricultura) - Universidade Estadual de Ponta Grossa, Ponta Grossa, 2009.

NOGUEIRA, M. A.; MELO, W. J. Enxofre disponível para a soja e a atividade de arilsulfatase em solo tratado com gesso agrícola. Revista Brasileira de Ciência do Solo, Viçosa, v. 27, n. 4, p. 655-663, 2003.

https://doi.org/10.1590/S0100-06832003000400010

PAVINATO, P. S.; ROSOLEM, C. A. Disponibilidade de nutrientes no solo - decomposição e liberação de compostos orgânicos de resíduos vegetais. Revista Brasileira de Ciência do Solo, Viçosa, v. 32, n. 3, p. 911920, 2008. https://doi.org/10.1590/S0100-06832008000300001

PRADO, R. de M. Efeito residual do calcário sob diferentes modos de incorporação antes da instalação do sistema plantio direto. Revista Brasileira de engenharia Agrícola e Ambiental, Campinas Grande, v.7, n. 3, p. 478-482, 2003. https://doi.org/10.1590/S1415-43662003000300012

QUAGGIO, J. A.; RAIJ, B. van; GALLO, P. B. \& MASCARENHAS. Respostas da soja à aplicação de calcário e gesso e lixiviação de íons no perfil do solo. Pesquisa Agropecuária Brasileira. v. 28, p. 375-383, 1993.

SILVA, N.M.; HIROCE, R.; QUAGGIO, J.A. A calagem na reação do algodoeiro à adubação com superfosfato simples. Bragantia, Campinas, v. 46, n. 2, p. 381-396, 1987. https://doi.org/10.1590/S000687051987000200018

SILVA, N.M.; CARVALHO, L.H.; QUAGGIO, J.A. Ensaio de longa duração com calcário e cloreto de potássio na cultura do algodoeiro. Bragantia, Campinas, v. 54, n. 2, p.353-360, 1995. https://doi.org/10.1590/S000687051995000200014

SILVA, N.M.; RAIJ, B. van; CARVALHO, L. H.; BATAGLIA, O.C.; KONDO, J.I. Efeitos do calcário e do gesso nas características químicas do solo e na cultura do algodão. Bragantia, v. 56. n. 2, p. 67-79, 1997. https://doi.org/10.1590/S0006-87051997000200018

SOUZA, D.M.G.; LOBATO, E.; REIN, T. A. O aumento da produção no cerrado com o uso de gesso agrícola. Potafos. 2001.

SOUZA, D.M.G.; LOBATO, S.; REIN, T.A. Uso de gesso agrícola nos solos do Cerrado. Planaltina, Embrapa Cerrados, 2005. 19p. (Circular Técnica, 32). 